\title{
Antioxidant Potential of Himalayan Medicinal Plants Angelica glauca, Alysicarpus vaginalis and Peristrophe bicalyculata
}

\author{
Prashant Arya* and J.P. Mehta \\ Department of Botany and Microbiology, H.N.B. Garhwal University Srinagar (Garhwal), India \\ *Corresponding author
}

\section{A B S T R A C T}

\begin{tabular}{|l|}
\hline Ke y w or d s \\
2, 2-diphenyl-1- \\
picryl hydrazyl, \\
Antioxidant, \\
$\begin{array}{l}\text { Phenol, Radical } \\
\text { scavenger. }\end{array}$ \\
\hline Article Info \\
\hline $\begin{array}{l}\text { Accepted: } \\
\text { 21 June } 2017 \\
\text { Available Online: } \\
10 \text { July } 2017\end{array}$ \\
\hline
\end{tabular}

The petroleum ether, chloroform, methanol and aqueous extract of Angelica glauca Edgew, Alysicarpus vaginalis (L.) DC and Peristrophe bicalyculata (Retz.) Nees were screened for their free radical scavenging properties using ascorbic acid, BHA and rutin as standard antioxidant. Free radical scavenging activity was evaluated using 2, 2-diphenyl-1-picryl hydrazyl (DPPH) free radical. The overall strongest antioxidant activity was found in methanolic extract for all the plants, The methanolic extract of A. glauca \%inhibition of DPPH radical is up to $95.81 \%$, A. vaginalis \%inhibition of DPPH radical is up to $90.36 \%$ and P. bicalyculata \% inhibition of DPPH radical is up to $86.33 \%$. The $\mathrm{IC}_{50}$ values of the extracts ranged between 69.42 to $475.36 \mu \mathrm{g} / \mathrm{ml}$ and standard antioxidant levels varied from 21.49 to $157.63 \mu \mathrm{g} / \mathrm{ml}$. The present study reveals that the selected plants would exert several beneficial effects by virtue of their antioxidant activity and could be harnessed as drug formulation. These plants may be used as a source of strong natural antioxidants.

\section{Introduction}

An antioxidant is a molecule that inhibits the oxidation of other molecules. The definition of antioxidants, given in 1995 by Halliwell and Gutteridge, stated that an antioxidant is "any substance that, when present at low concentrations compared with that of an oxidizable substrate, significantly delays or inhibits oxidation of that substrate" (Halliwell and Gutteridge, 1995). In 2007, Halliwell gave a more specific definition, stating that an antioxidant is "any substance that delays, prevents or removes oxidative damage to a target molecule" (Halliwell, 2007). Our body is rich in endogenous antioxidants, the substances that have the ability to stop free radicals formation or to limit the damage they cause (Tomas et al., 1997). The effectiveness of current used exogenous antioxidants arises most probably from the increase of the endogenous free radical scavengers as enzymes (superoxide dismutase and selenium-dependent glutathione peroxidase), vitamins (alpha tocopherol and ascorbic acid). Many plants have also been found to possess free radical scavenging activity (polyphenols, alkaloids and terpenoids). Low levels of one or more of the essential antioxidants have been shown to be associated with many disorders including cancer, inflammation, atherosclerosis, 
coronary heart disease and diabetes. Many medicinal herbs contain antioxidant compounds which protects the cells against the damaging effects of reactive oxygen species.

Angelica glauca genus Angelica (family: Apiaceae) is recognised globally for its uses in traditional and modern system of medicine. The estimated 110-115 species of the genus worldwide, 87 species occur in Asia (Pimenov and Leonov, 2004). Three species namely Angelica glauca Edgew, $A$. archangelica $\mathrm{L}$. and $A$. nubigena $\mathrm{Cl}$. are reported from the Indian Himalaya (Samant et al., 1998). A. glauca, locally called as Choru or Gandravan, being native and endemic of the Himalayan region, is distributed along 2000 to 3,800m in Uttarakhand, Jammu and Kashmir and Himachal Pradesh (Butola and Badola, 2004). The species is well known for its aromatic as well as medicinal values.

Alysicarpus vaginalis genus Alysicarpus belongs to family Papilionaceae. There are approximately 78 species in their genus with 20 species are reported in India (Haines, 1978). They commonly found in open grass land, crop fields, way sides, to $1000 \mathrm{~m}$ Garhwal Himalaya, almost throughout India, ascending to $1000 \mathrm{~m}$ Afghanistan, Pakistan and tropical America.

The genus comprises annual Prostrate Herbs, perennial. Several species of Alysicarpus has been used in indigenous system of medicine an anti-inflammatory in stomachache, and also an antidote to snake bite. It is also used in skin diseases and as a diuretic. The leaves are used in fever and jaundice (Shankarnarayan, 1993).

Peristrophe bicalyculata genus Peristrophe belongs to family Acanthaceae, is an erect herbs, stem slender, branched $30-70 \mathrm{~cm}$ height found in forest undergrowth, hedges and waste band almost throughout India and in Garhwal Himalaya it is found at an altitude of 500 to $1,400 \mathrm{~m}$. The leaves of the plant were used traditionally as analgesic, antipyretic, anti-inflammatory, sedative, stomachic, anticancer, fertility, diuretics and diarrhea. $P$. bicalyculata is used by the traditional healers for curing many skin related problems; as an antidote for snake poison when macerated in an infusion of rice, and as an insect repellant (Abdulazeez et al., 2013). Paste of $P$. bicalyculata applied on wound, flowers use as source of bee-forage. The essential oil shows tuberculostatic activity in vitro. It inhibits the growth of various strains of Mycobacterium tuberculosis. Ayurvedic Pharmacopoeia of India recommends the dried root in insomnia and for fear-psychosis in children (Khare, 2007).

\section{Materials and Methods}

\section{Chemicals}

2,2-diphenyl-1-picryl-hydrazyl (DPPH), potassium persulfate, 2,2'-azinobis-(3 ethylbenzothiozoline-6-sulfonic acid)diammonium salt (ABTS), 6-hydroxy-2,5,7,8 tetramethylchroman-2-carboxylic acid (Trolox), Rutin, sodium nitroprusside, ferrozine, ferrous chloride, ethylenediamine tetracetic acid (EDTA) disodium salt, Butylated Hydroxyl Anisole (BHA) and ascorbic acid were obtained from Himedia Chemicals or Sigma. All other reagents used were of analytical grade.

\section{Collection and identification of plants}

The plants included in this study involve Angelica glauca (Stem and Root) collected from Tungnath- Chandrashilla and Track of Rudaranath (Rudraprayag), Alysicarpus vaginalis (Root) from Chauras and Kirtinagar (Tehri Garhwal) and Peristrophe bicalyculata (Leaves) collected from Chauras, Kirtinagar 
(Tehri Garhwal), Srinagar, Srikot and Pauri (Pauri Garhwal) Uttarakhand (Fig. 1). Plant were authenticated at Garhwal University Herbarium (GUH), a herbarium voucher specimen were submitted.

\section{Preparation of extract}

Collected plant materials was properly washed with water, dried under shade at room temperature and crushed to small pieces by using pestle and motor. The plant extracts were prepared by immersing $200 \mathrm{~g}$ of powdered plant material in $600 \mathrm{ml}$ of four different solvents according to polarity low to high i.e. petroleum ether (PET), chloroform (CHF), methanol (MeOH) and aqueous $\left(\mathrm{H}_{2} \mathrm{O}\right)$, loaded in Soxhlet assembly and extracted for $72 \mathrm{~h}$ through successive method (Ahmed et al., 1998). Plant extracts were filtered through Whatman No. 1 filter paper and crude extracts obtained by removing solvent in vacuum evaporator at $30^{\circ} \mathrm{C}$. Residues were stored at $4^{\circ} \mathrm{C}$ until further use.

\section{Evaluation of antioxidant activity}

\section{DPPH free radical scavenging activity}

DPPH (2, 2-diphenyl picryl hydrazyl) is a commercially available stable free radical, which is purple in colour. The antioxidant molecules present in the herbal extracts, when incubated, react with DPPH and convert it into di-phenyl hydrazine, which is yellow in colour. The degree of discoloration of purple to yellow was measured at $517 \mathrm{~nm}$, which is a measure of scavenging potential of plant extracts.

A $2 \mathrm{ml}$ aliquot of solution was added to $2 \mathrm{ml}$ of $2 \times 10^{-4} \mathrm{~mol} / \mathrm{L}$ ethanolic DPPH solution. The mixture was shaken vigorously and the absorbance was measured at $517 \mathrm{~nm}$ immediately. The decrease in absorbance was determined at 15 and $30 \mathrm{~min}$ until the absorbance reached a steady state (after nearly 30 minute). The DPPH with corresponding solvents (without plant material) serves as the positive control. The respective solvent of plant extracts (without DPPH) serves as blank (Sheng et al., 2011). All the tests were performed in triplicate and the DPPH radical scavenging activity of the plant extract was calculated as the percentage inhibition according to the formula:

\% Inhibition of DPPH free radical $=\left[\frac{\left(\mathrm{A}_{\text {blank }}-\mathrm{A}_{\text {gample }}\right)}{\mathrm{A}_{\text {blank }}}\right] \times 100$

\section{Results and Discussion}

\section{DPPH free radical scavenging ability}

DPPH (2, 2-diphenyl-1-picrylhydrazyl) radical changes its colour from purple to yellow in the presence of antioxidant and is most widely used to evaluate the antioxidant potential of extracts. The method is based on the hydrogen donating capability of the extract which scavenges DPPH free radical. Scavenging of the DPPH radical is also linked to the inhibition of lipid peroxidation.

The results of the assay demonstrated antioxidant activity of Angelica glauca extracts suggesting that the extracts are capable of donating hydrogen and acting as natural antioxidants. The methanolic extract of A. glauca (Fig. 4) was potent in scavenging DPPH radical in comparison to petroleum ether (Fig. 2), chloroform (Fig. 3) and aqueous extract (Fig. 5). The methanolic extract of A. glauca \% inhibition of DPPH radical is up to $95.81 \%$. The radical scavenging ability was significantly low when compared to synthetic antioxidants like BHA and ascorbic acid. The scavenging ability of the methanol extract was however comparable to rutin. The potential to scavenge DPPH radical was measured by determining $\mathrm{IC}_{50}$ value which indicate the concentration 
required to inhibit $50 \%$ of $\mathrm{DPPH}$ free radicals. Lower values of $\mathrm{IC}_{50}$ indicate higher potency to scavenging DPPH free radicals of plants extract. $\mathrm{IC}_{50}$ value of the methanolic extract $(69.42 \mu \mathrm{g} / \mathrm{ml})$ was much lower in comparison to chloroform extract (100.71 $\mu \mathrm{g} / \mathrm{ml})$, petroleum ether extract $(261.35$ $\mu \mathrm{g} / \mathrm{ml})$ and water extract $(231.65 \mu \mathrm{g} / \mathrm{ml})$ of $A$. glauca (Fig 15). The $\mathrm{IC}_{50}$ value of methanolic extract $(69.42 \mu \mathrm{g} / \mathrm{ml})$ and chloroform extract $(100.71 \mu \mathrm{g} / \mathrm{ml})$ of $A$. glauca is much lower in comparable to standard synthetic antioxidant BHA $(157.63 \mu \mathrm{g} / \mathrm{ml})$ but higher than the other synthetic antioxidant like rutin $(45.19 \mu \mathrm{g} / \mathrm{ml})$ and ascorbic acid (21.43 $\mu \mathrm{g} / \mathrm{ml})$ (Fig. 15).

The methanol extract of $A$. vaginalis (Fig. 8) was potent in scavenging DPPH radical in comparison to chloroform (Fig. 7), petroleum ether (Fig. 6) and aqueous extract (Fig. 9). The methanolic extract of A. vaginalis \% inhibition of DPPH radical is up to $90.36 \%$. The $\mathrm{IC}_{50}$ value of methanol extract was $(144.92 \mu \mathrm{g} / \mathrm{ml})$, chloroform extract $(243.64$ $\mu \mathrm{g} / \mathrm{ml})$, petroleum ether extract (475.36 $\mu \mathrm{g} / \mathrm{ml})$ and aqueous (371.17 $\mu \mathrm{g} / \mathrm{ml})$ (Fig. 15). The $\mathrm{IC}_{50}$ value of methanolic extract (144.92 $\mu \mathrm{g} / \mathrm{ml})$ is lower than synthetic antioxidant BHA (157.63 $\mu \mathrm{g} / \mathrm{ml})$ (Fig. 14).

The methanol extract of $P$. bicalyculata (Fig. 12) exhibited maximum potency in scavenging DPPH radical in comparison to petroleum ether (Fig. 10), chloroform (Fig.
11) and aqueous extract (Fig. 13). The methanolic extract of $P$. bicalyculata \% inhibition of DPPH radical is up to $86.33 \%$ it's lower than other two medicinal plants. $\mathrm{IC}_{50}$ value of the methanolic extract (153.79 $\mu \mathrm{g} / \mathrm{ml}$ ) was much lower than that of chloroform $(330.16 \mu \mathrm{g} / \mathrm{ml})$, petroleum ether extract $(243.79 \mu \mathrm{g} / \mathrm{ml})$ and aqueous extract (272.26 $\mu \mathrm{g} / \mathrm{ml}$ ) (Fig. 15). IC $_{50}$ value of methanolic extract of $P$. bicalyculata was comparable to BHA $(157.79 \mu \mathrm{g} / \mathrm{ml})$, however it was much higher than synthetic antioxidant rutin $(45.19 \mu \mathrm{g} / \mathrm{ml})$ and ascorbic acid $(21.43$ $\mu \mathrm{g} / \mathrm{ml}$ ) (Fig. 14). Lower value of $\mathrm{IC}_{50}$ of the extract showed the potent antioxidant activity presence in the extracts.

The best antioxidant activity was showed by methanolic extract of $A$. glauca in comparison to other two medicinal plants. Joshi et al., (2008) reported antioxidant activity of water extract of $A$. glauca, the scavenging activity of the water extract ranged from $14.58 \%$ to $71.53 \%$ as the concentration increased 5 to 25 $\mathrm{mg} / \mathrm{ml}$. The extract exhibited moderate scavenging activity, which was less than the standards. But in the present observation water extract of A. glauca showed $50.94 \%$ to $69.36 \%$ inhibition in 100 to $400 \mu \mathrm{g} / \mathrm{ml}$ concentration. Irshad et al., (2011) reported that the essential oil of A. glauca exhibited good DPPH radical scavenging activity showing (93.4\% of inhibition and $45.05 \%$ inhibition of peroxidation).

\section{Collection and identification of plants}

\begin{tabular}{|l|l|c|}
\hline Name of plants & Family & Accession No. \\
\hline Angelica glauca Edgew. & Apiaceae & GUH 20748 \\
\hline Alysicarpus vaginalis (L.) DC. & Fabaceae & GUH 20749 \\
\hline $\begin{array}{l}\text { Peristrophe bicalyculata (Retz.) } \\
\text { Nees }\end{array}$ & Acanthaceae & GUH 20750 \\
\hline
\end{tabular}


Fig.1 Map of medicinal plants collection sites
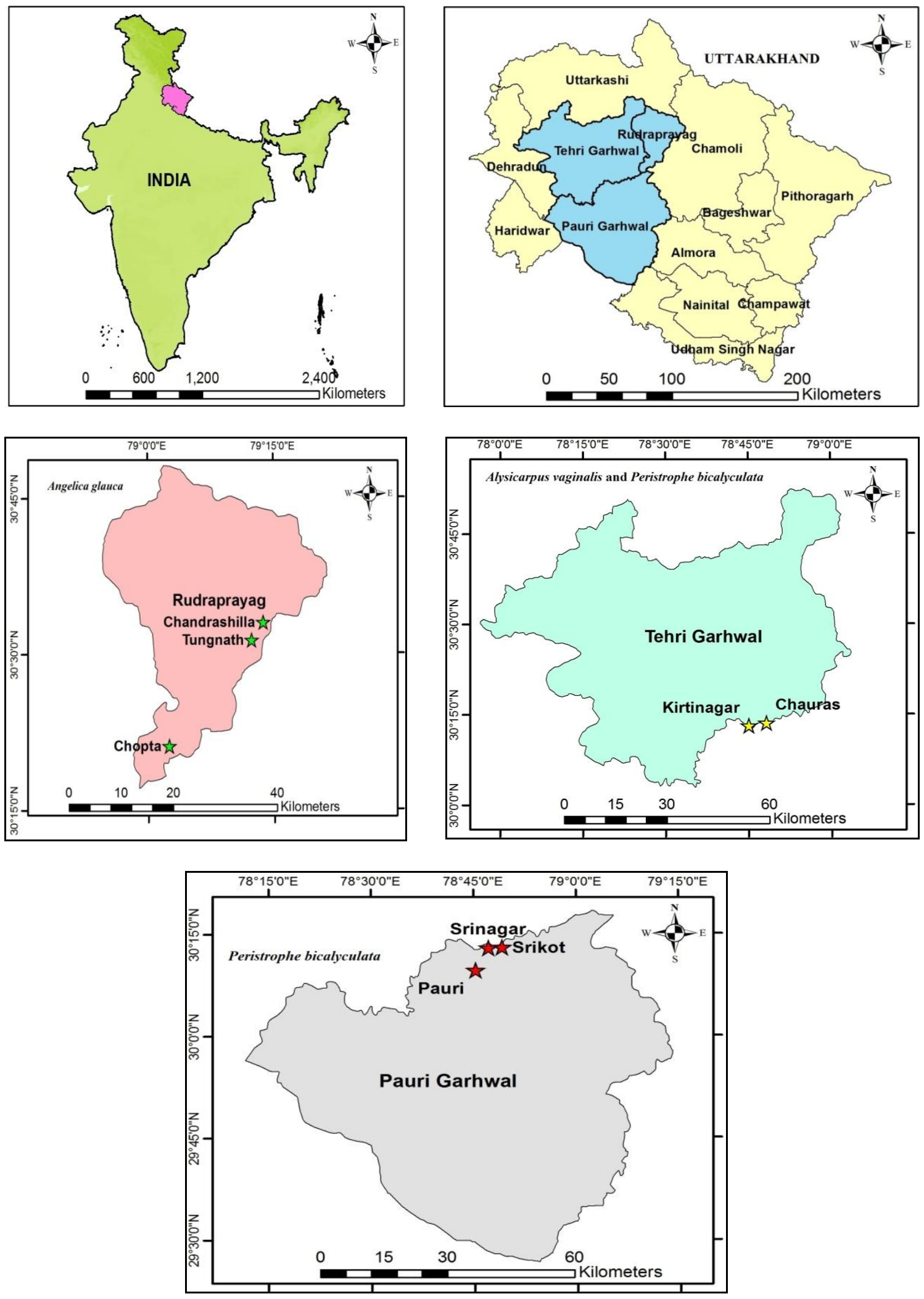
Fig. $2 \%$ Inhibition of DPPH free radicals by $A$. glauca petroleum ether extract

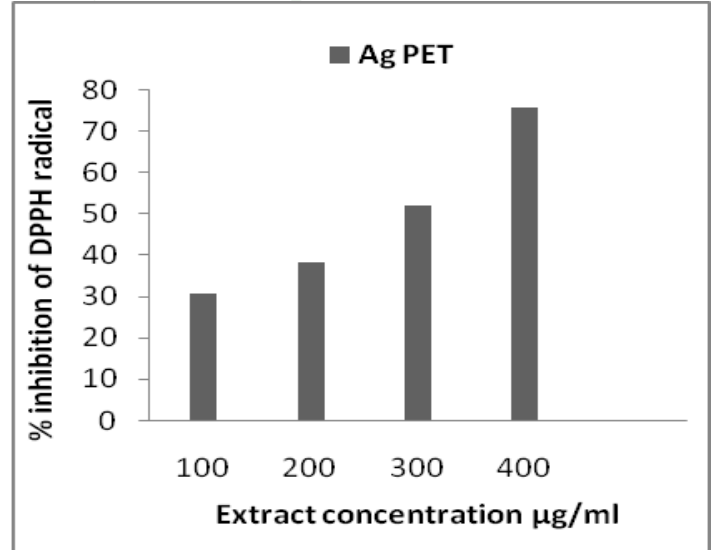

Fig.4 \% Inhibition of DPPH free radicals by A. glauca methanol extract

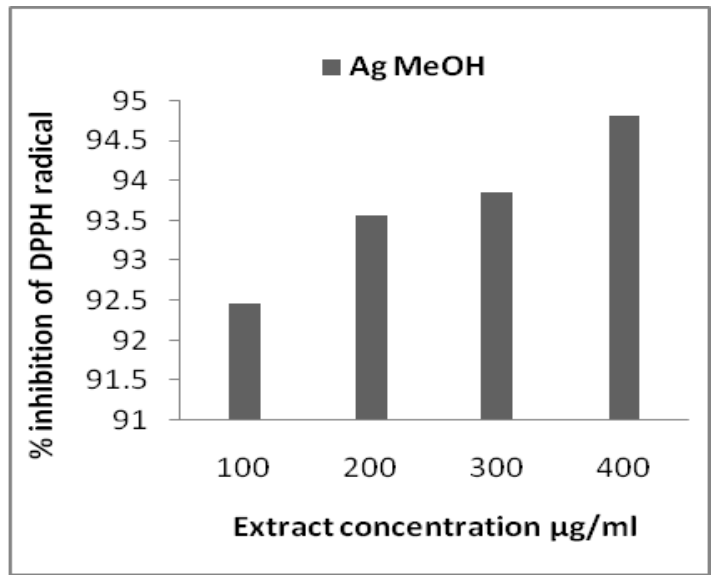

Fig. $6 \%$ Inhibition of DPPH free radicals by $A$. vaginalis petroleum ether extract

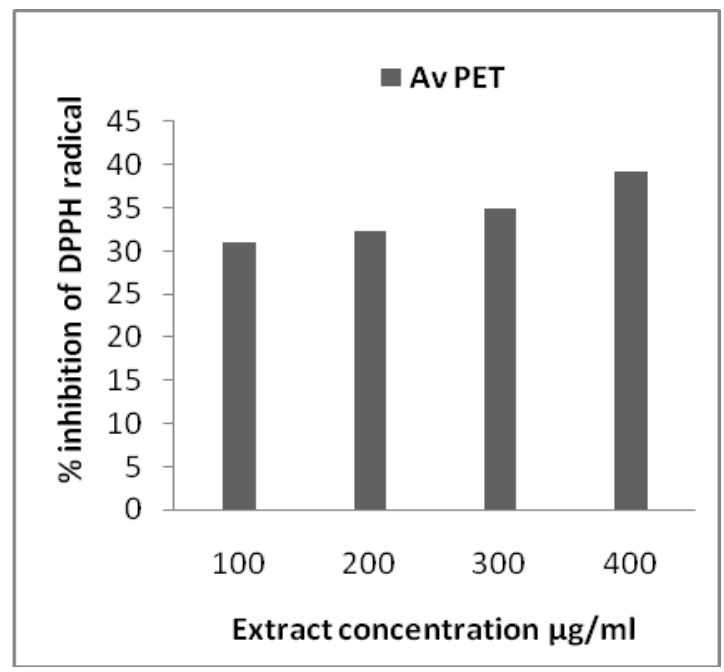

Fig.3 \% Inhibition of DPPH free radicals by $A$. glauca chloroform extract

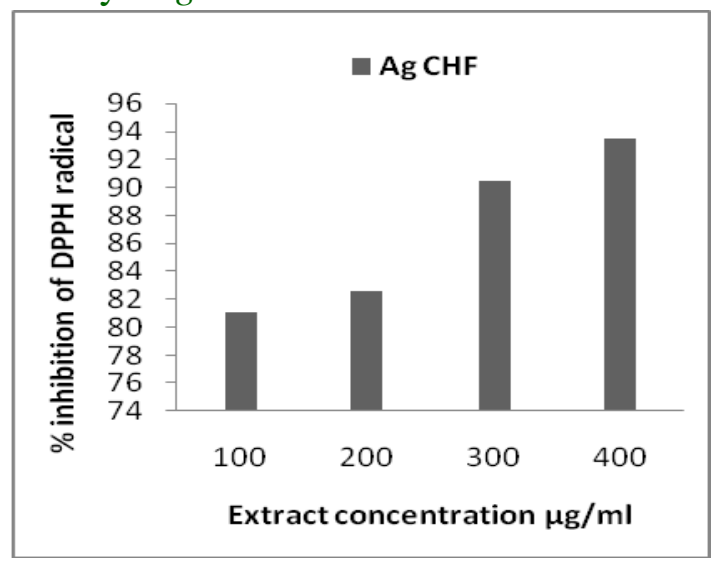

Fig.5 \% Inhibition of DPPH free radicals by $A$. glauca aqueous extract

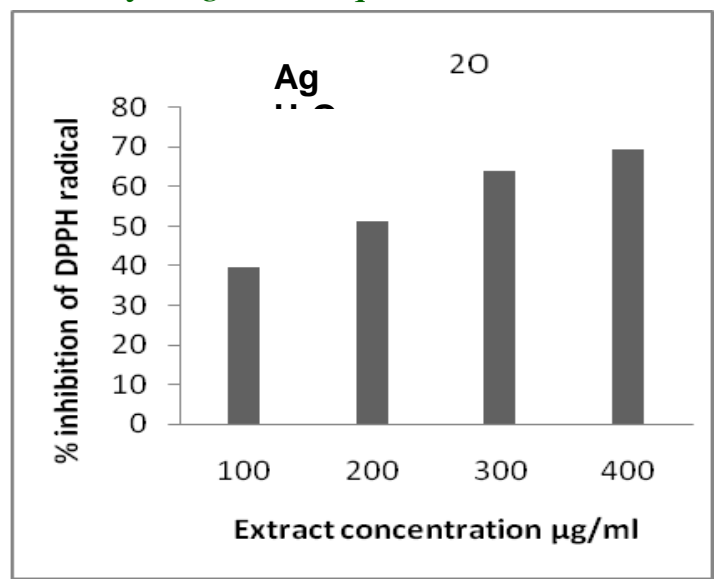

Fig. $7 \%$ Inhibition of DPPH free radicals by A. vaginalis chloroform extract

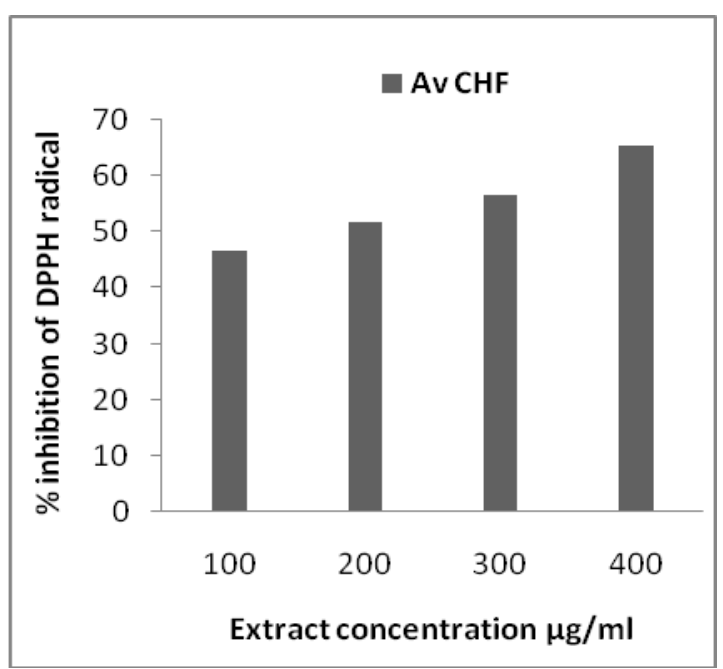


Fig.8 \% Inhibition of DPPH free radicals

by $A$. vaginalis methanol extract

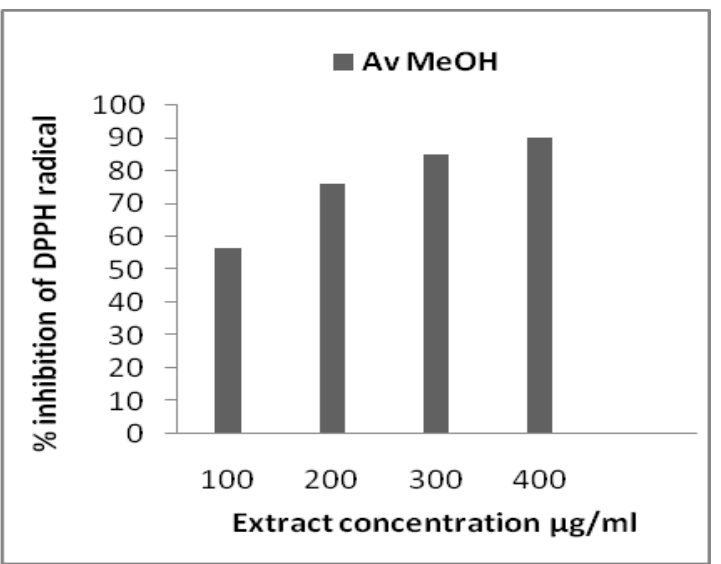

Fig.10 \% Inhibition of DPPH free radicals by $P$. bicalyculata petroleum ether extract

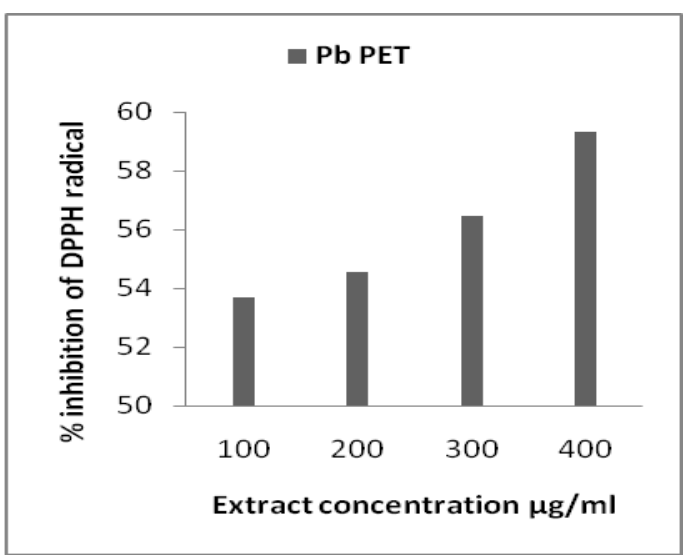

Fig.12 \% Inhibition of DPPH free radicals by $P$. bicalyculata methanol extract

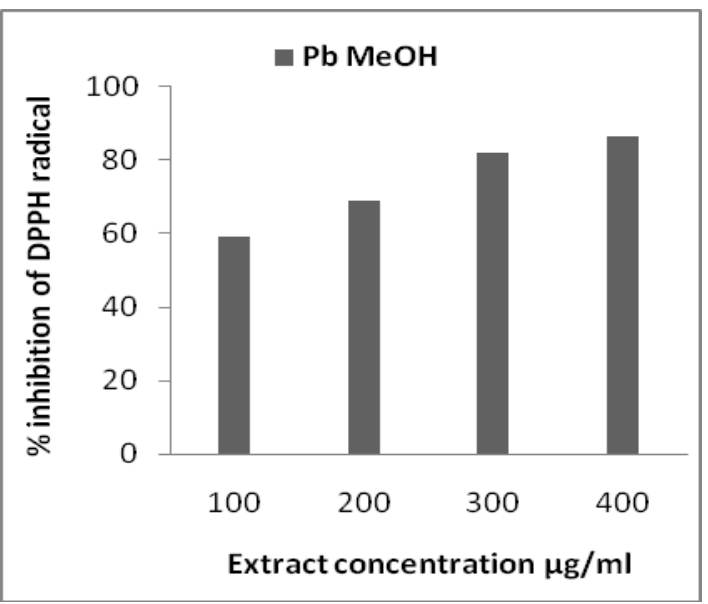

Fig.9 \% Inhibition of DPPH free radicals by $A$. vaginalis aqueous extract

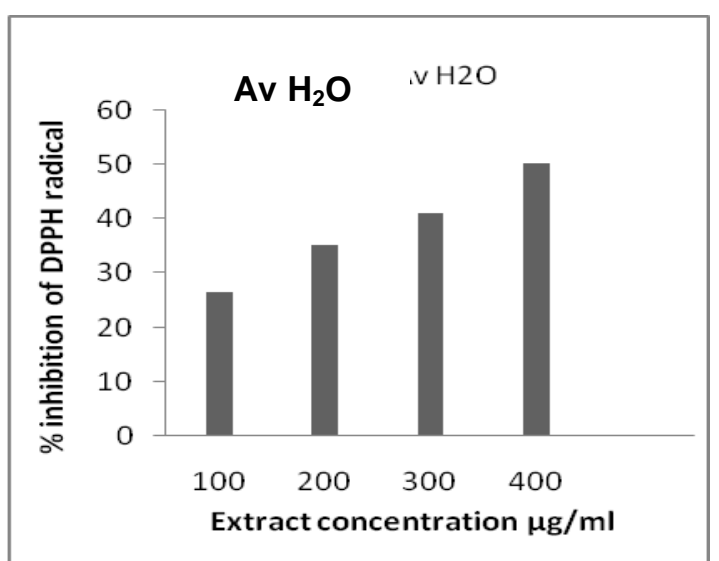

Fig.11\% Inhibition of DPPH free radicals by $P$. bicalyculata chloroform extract

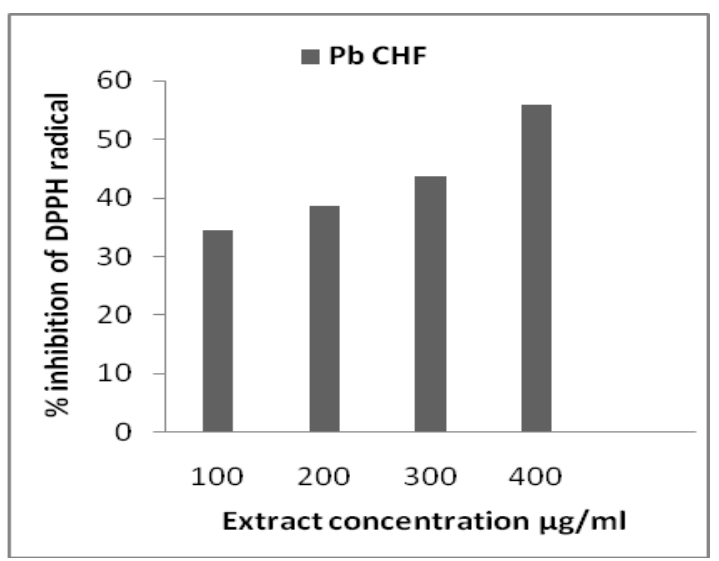

Fig.13\% Inhibition of DPPH free radicals by $P$. bicalyculata aqueous extract

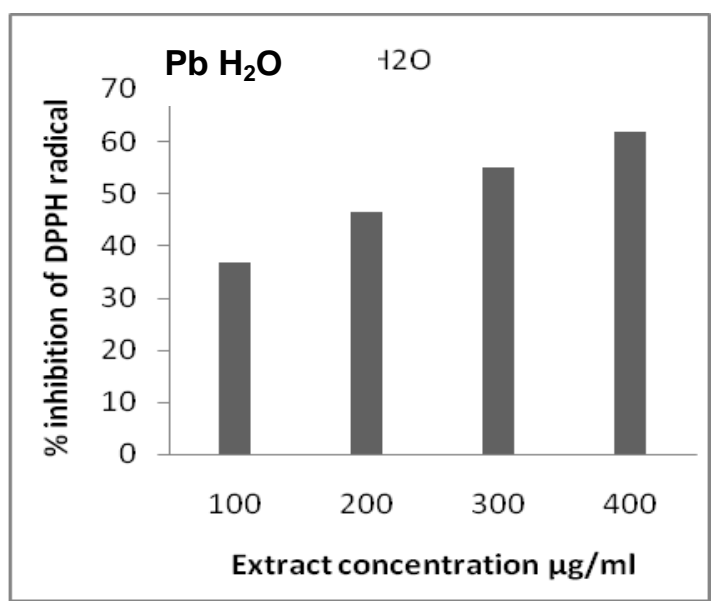


Fig.14 Comparison of the DPPH free radicals scavenging ability by methanolic extracts of A. glauca, $A$. vaginalis and $P$. bicalyculata with standard antioxidant.

$\mathrm{BHA}=$ Butylated Hydroxyl Anisole, Ag $\mathrm{MeOH}=$ Methanolic extract of A. glauca, Av $\mathrm{MeOH}=$ Methanolic extract of $A$. vaginalis, $\mathrm{Pb} \mathrm{MeOH}=$ Methanolic extract of $P$. bicalyculata

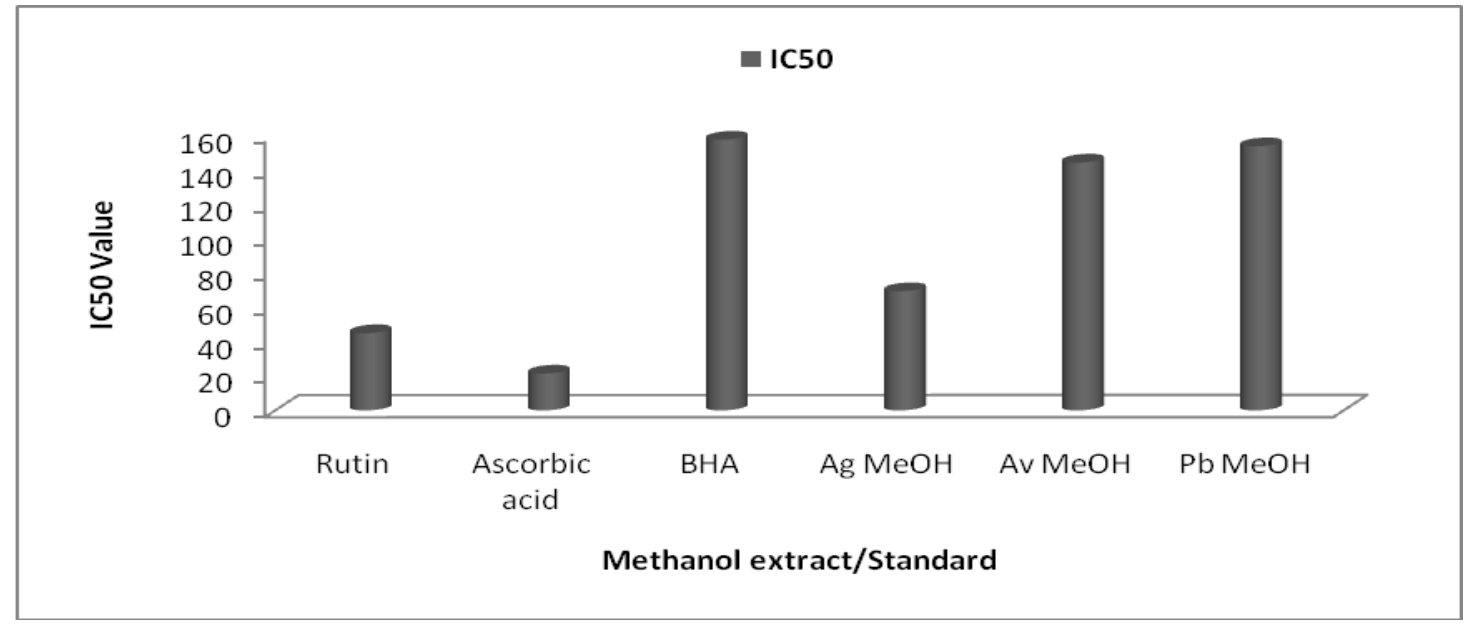

Fig.15 Comparison of the DPPH free radicals scavenging ability by various extracts of $A$. glauca, A. vaginalis and $P$. bicalyculata with standard antioxidant.

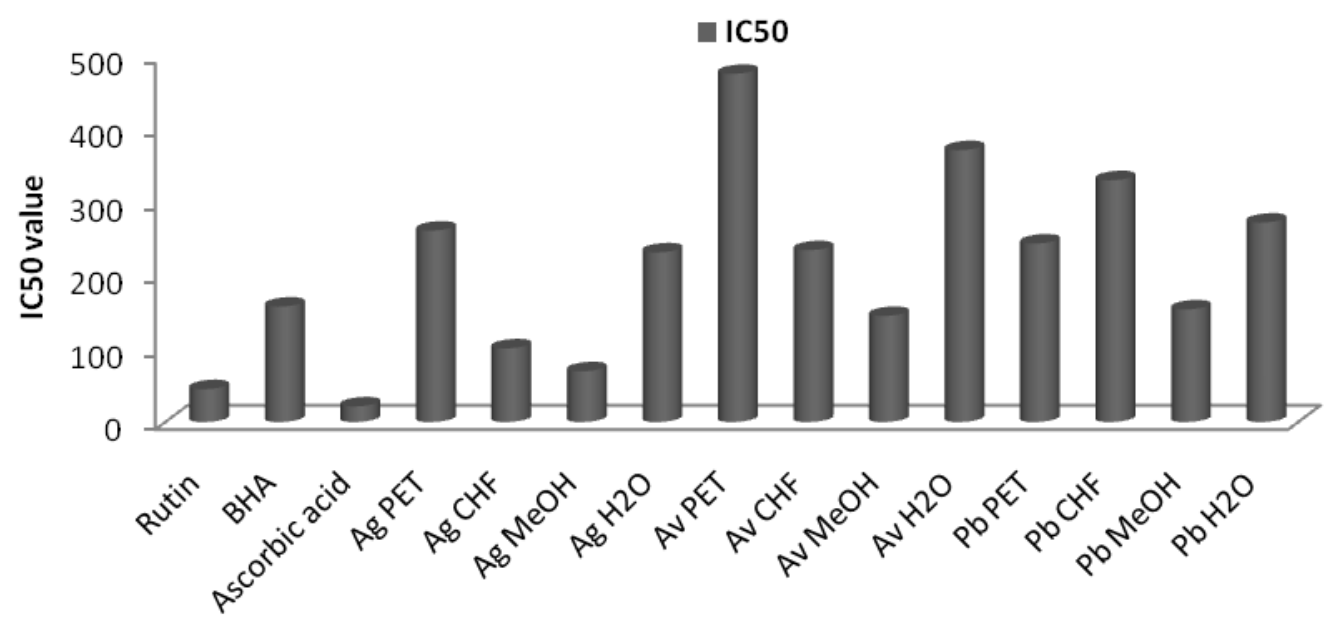

Extract/Standard

Note: BHA (butylated hydroxyl anisole), RUTIN, AA (ascorbic acid), DPPH (2, 2-diphenyl-1-picrylhydrazyl). Ag PET, $\mathrm{Ag} \mathrm{CHF}, \mathrm{Ag} \mathrm{MeOH}, \mathrm{Ag} \mathrm{H}_{2} \mathrm{O}$ is petroleum ether, chloroform, methanol and aqueous extracts of A. glauca. Av PET, Av CHF, Av MeOH, Av $\mathrm{H}_{2} \mathrm{O}$ are petroleum ether, chloroform, methanolic and aqueous extracts of $A$. vaginalis. $\mathrm{Pb} \mathrm{PET}, \mathrm{Pb}$ CHF, $\mathrm{Pb} \mathrm{MeOH}, \mathrm{Pb} \mathrm{H}_{2} \mathrm{O}$ - petroleum ether, chloroform, methanolic and aqueous extracts of $P$. bicalyculata respectively.

On the basic of prior published report minimum work has been done on antibacterial and antioxidant activity of medicinal creeping annual herbs A. vaginalis. Narintorn et al., (2014) reported the antioxidant activity of water and ethanol extract of A. vaginalis. The highest antioxidant activity was found in DPPH method by ethanolic extract of $A$. vaginalis. $\mathrm{IC}_{50}$ value of ethanolic extract was $(345.70 \mu \mathrm{g} / \mathrm{ml})$ and water extract (381.98 
$\mu \mathrm{g} / \mathrm{ml})$. The lowest $\mathrm{IC}_{50}$ value indicates the highest potency of inhibition or scavenging. In the present study the $\mathrm{IC}_{50}$ value of aqueous extract of $A$. vaginalis is $371.17 \mu \mathrm{g} / \mathrm{ml}$ and methanolic extract is $144.92 \mu \mathrm{g} / \mathrm{ml}$.

Johnley et al., (2014) reported the antioxidant activity of whole plant of $P$. bicalyculata by DPPH method. They used the three solvent petroleum ether, methanol and ethyl acetate. The results showed highest antioxidant activity by methanol extract in $1000 \mu \mathrm{g} / \mathrm{ml}$ concentration $(63.15 \%)$ followed by same concentration of petroleum ether $(50.28 \%)$ and ethyl acetate $(55.45 \%)$. The $\mathrm{IC}_{50}$ value of methanolic extract is $(612 \mu \mathrm{g} / \mathrm{ml})$, petroleum ether extract $(1020 \mu \mathrm{g} / \mathrm{ml})$ and ethyl acetate extract $(830 \mu \mathrm{g} / \mathrm{ml})$ in $1000 \mu \mathrm{g} / \mathrm{ml}$ concentration. Rutin used as standard give $\mathrm{IC}_{50}$ value $(480 \mathrm{mg} / \mathrm{ml})$ on methanol, petroleum ether and ethyl acetate. Another researcher work on antioxidant activity of water, ethanol and acetone extract of $P$. bicalyculata by DPPH method on $50 \mu \mathrm{g} / \mathrm{ml}$ concentration. The $\mathrm{IC}_{50}$ value of water extract is $(471 \mu \mathrm{g} / \mathrm{ml})$, ethanol $(501 \mu \mathrm{g} / \mathrm{ml})$ and acetone extract $(144.7 \mu \mathrm{g} / \mathrm{ml})$. The maximum scavenging percentage was found in acetone extract than ethanol and water extract of $P$. bicalyculata. Krishnamoorthy et al., (2014) determine the antioxidant activity of water ethanol and acetone extract of $P$. bicalyculata by DPPH method on $50 \mathrm{mg} / \mathrm{ml}$ concentration.

In this paper we reported the data of antioxidant activities of different extracts of A. glauca, A. vaginalis and P. bicalyculata. The methanol extract of A. glauca, $A$. vaginalis and $P$. bicalyculata showed the highest value of total antioxidant capacity as compare to other extract. The methanol extract of A. glauca demonstrated significant reducing power in the concentration 100 to $400 \mu \mathrm{g} / \mathrm{ml}$ range between $90.43 \%$ and $94.81 \%$ of inhibition. The methanolic extract of $A$. vaginalis exhibited significant reducing power in the concentration range of 100-400 $\mu \mathrm{g} / \mathrm{ml}$ and also the methanolic extract of $P$. bicalyculata exhibited highest reducing power than other extract. In all the plants extract the methanolic extract of A. glauca showed highest reducing power $(95.81 \%)$, which was even better than other extract in the concentration range of $100-400 \mu \mathrm{g} / \mathrm{ml}$. Minimum values of $\mathrm{IC}_{50}$ indicate maximum potency to scavenging DPPH free radicals of plants extract. $\mathrm{IC}_{50}$ value of the methanolic extract of $A$. glauca was $69.42 \mu \mathrm{g} / \mathrm{ml}, \mathrm{IC}_{50}$ value of methanol extract of $A$. vaginalis was $144.92 \mu \mathrm{g} / \mathrm{ml}$ and $\mathrm{IC}_{50}$ value of the methanolic extract was $153.79 \mu \mathrm{g} / \mathrm{ml}$. $P$. bicalyculata showed the potent DPPH free radical scavenging ability in the extracts which is better than the synthetic antioxidant BHA $(157.63 \mu \mathrm{g} / \mathrm{ml})$. The methanolic extract of A. glauca on $400 \mu \mathrm{g} / \mathrm{ml}$ concentration showed the maximum inhibition (95.81\%) followed by $A$. vaginalis $(90.36 \%)$ and $P$. bicalyculata (86.33\%). The methanolic extract of $A$. glauca, A. vaginalis and $P$. bicalyculata showed effective antioxidant activity. In other words we can say these plants are used as a natural source of strong antioxidant.

\section{Acknowledgement}

This work was financially supported by $U$ G C New Delhi and Department of Botany and Microbiology H N B Garhwal University (A Central University) Srinagar (Garhwal). The authors are thankful to Curator of Garhwal University Herbarium (GUH), H. N. B. Garhwal University Srinagar (Garhwal) for medicinal plant identification.

\section{References}

Halliwell, B., and J M C, Gutteridge. 1995. The Definition and Measurement of Antioxidants in Biological Systems. Free 
Radical Biology and Medicine 18(1):125-126.

Halliwell, B., 2007. Biochemistry of Oxidative Stress. Biochemical Society Transactions, 35(5):1147-1150.

Tomas-Barberan, F A., and Robins, R J. 1997. Phytochemistry of Fruits and vegetables. Caledon Press, Oxford, New York.

Pimenov, M G., and Leonov, M V. 2004. The Asian umbelliferae biodiversity database (ASIUM) with particular reference to South-West Asian taxa. Turkish Journal of Botany 2(7)34-39.

Samant, S S., Dhar, U., and Palni, L M S. 1998. Medicinal Plants of Indian Himalaya Diversity Distribution Potential Values. HIMAVIKAS Publication No. 13 Nainital Gyanodaya Prakashan139-145.

Butola, J S., and Badola, H K. 2004. Effect of pre-sowing treatment on seed germination and seedling vigour in Angelica glauca, a threatened medicinal herb. Current Science 87:796-799.

Haines, H H., 1978. Botany of Bihar and Orissa. Part-III, IV (eds) Botanical Survey of India Calcutta.

Satynarayana, N V., Lachake, S H., and Chauhan, M 1993. Pharmacognostical and phytochemical investigation of Peristrophe bicalyculata. Ancient Science of Life 12(34):420-427.

Khare, C P., 2007. Indian Medicinal Plants. Springer-Verlag Berlin/Heidelberg 52-53.

Abdulazeez, M A., Ibrahim, A D., Ayo, J O., and Carvalho, L G C. 2013. Anticancer Activities of extracts of Peristrophe bicalyculata (RETZ) NEES. Romanian Biotechnol. Letters 18(1): 7995-8006.

Sheng, Zhan-Wu., Wei-Hong, M., Jin-He, G., Yang, B., Wei-Min, Z., Hua-Ting, D., and Zhi-Qiang, Jin. 2011. Antioxidant properties of banana flower of two cultivars in China using 2,2-diphenyl-1picrylhydrazyl (DPPH,) reducing power, 2,2'-azinobis- (3-ethylbenzthiazoline-6sulphonate (ABTS) and inhibition of lipid peroxidation assays. African Journal of Biotechnology.10(21):4470-4477.

Joshi, S., Om, P., Subrata, K H., Anjum, Z., and Anil, K P. 2008. Hepatoprotective and antioxidant activity of the aqueous extract of Angelica glauca Edgew. Root. Asian Journal of Traditional Medicines 3:(2)58-66.

Irshad, M., Habib-ur-R, Muhammad S., Shahid, A., and Tahsin, G. 2011. Antioxidant, Antimicrobial and Phytotoxic Activities of Essential Oil of Angelica glauca. Asian Journal of Chemistry. 23(5):1947-1951.

Narintorn, R., Sakda, D., Suthep, P., Wandee, B., Bundit, P., Ratree, T., Phangthip, U., Patcharee, B., and Jureerut, D. 2014. Antioxidant and antibacterial properties of selected Thai weed extracts. Asian Pacific Journal of Tropical Biomedicine 4(11):890-895.

Krishnamoorthy, K., Krishnaswamy, T., Subramaniam, P., and Sellamuthu, M. 2014. Quantification of phytochemicals and in vitro antioxidant potential of various solvent extracts of certain species of Acanthaceae. International Journal of Green Pharmacy 8:58-64.

\section{How to cite this article:}

Prashant Arya and Mehta, J.P. 2017. Antioxidant Potential of Himalayan Medicinal Plants Angelica glauca, Alysicarpus vaginalis and Peristrophe bicalyculata. Int.J.Curr.Microbiol.App.Sci. 6(7): 1892-1901. doi: https://doi.org/10.20546/ijcmas.2017.607.226 